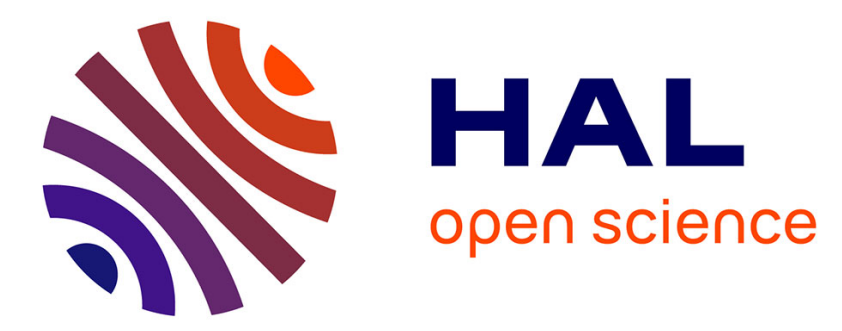

\title{
Effect of cutting parameters on surface integrity of monocrystalline silicon sawn with an endless diamond wire saw
}

Erick Cardoso Costa, Fabio Antonio Xavier, Ricardo Knoblauch, Cristiano Binder, Walter Lindolfo Weingaertner

\section{To cite this version:}

Erick Cardoso Costa, Fabio Antonio Xavier, Ricardo Knoblauch, Cristiano Binder, Walter Lindolfo Weingaertner. Effect of cutting parameters on surface integrity of monocrystalline silicon sawn with an endless diamond wire saw. Solar Energy, 2020, 207, pp.640-650. 10.1016/j.solener.2020.07.018 . hal-03170941

\section{HAL Id: hal-03170941 \\ https://hal.science/hal-03170941}

Submitted on 19 Mar 2021

HAL is a multi-disciplinary open access archive for the deposit and dissemination of scientific research documents, whether they are published or not. The documents may come from teaching and research institutions in France or abroad, or from public or private research centers.
L'archive ouverte pluridisciplinaire HAL, est destinée au dépôt et à la diffusion de documents scientifiques de niveau recherche, publiés ou non, émanant des établissements d'enseignement et de recherche français ou étrangers, des laboratoires publics ou privés. 


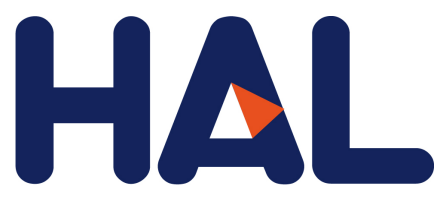

archives-ouvertes

\section{Effect of cutting parameters on surface integrity of monocrystalline silicon sawn with an endless diamond wire saw}

Erick Cardoso Costa, Fabio Antonio Xavier, Ricardo Knoblauch, Cristiano Binder, Walter Lindolfo Weingaertner

\section{To cite this version:}

Erick Cardoso Costa, Fabio Antonio Xavier, Ricardo Knoblauch, Cristiano Binder, Walter Lindolfo Weingaertner. Effect of cutting parameters on surface integrity of monocrystalline silicon sawn with an endless diamond wire saw. Solar Energy, Elsevier, 2020, 207, pp.640-650. hal-03170941

\section{HAL Id: hal-03170941 \\ https://hal.archives-ouvertes.fr/hal-03170941}

Submitted on 19 Mar 2021

HAL is a multi-disciplinary open access archive for the deposit and dissemination of scientific research documents, whether they are published or not. The documents may come from teaching and research institutions in France or abroad, or from public or private research centers.
L'archive ouverte pluridisciplinaire HAL, est destinée au dépôt et à la diffusion de documents scientifiques de niveau recherche, publiés ou non, émanant des établissements d'enseignement et de recherche français ou étrangers, des laboratoires publics ou privés. 


\title{
Effect of cutting parameters on surface integrity of monocrystalline silicon sawn with an endless diamond wire saw
}

\author{
Erick Cardoso Costa ${ }^{\mathrm{a}, *}$, Fabio Antonio Xavier ${ }^{\mathrm{a}}$, Ricardo Knoblauch ${ }^{\mathrm{b}}$, Cristiano Binder ${ }^{\mathrm{c}}$, \\ Walter Lindolfo Weingaertner ${ }^{\mathrm{a}}$ \\ ${ }^{\text {a }}$ Precision Engineering Laboratory (LMP), Mechanical Engineering Department, Universidade Federal de Santa Catarina, Florianopolis, SC, Brazil \\ ${ }^{\mathrm{b}}$ MSMP Laboratory, Ecole Nationale Supérieure d'Arts et Métiers ParisTech, Aix-en-Provence 13671, France \\ ${ }^{\mathrm{c}}$ Materials Laboratory (LabMat), Mechanical Engineering Department, Universidade Federal de Santa Catarina, Florianopolis, SC, Brazil
}

\section{A R T I C L E I N F O}

\section{Keywords:}

Diamond wire sawing

Mono-Si

Surface integrity

Brittle-ductile transition

Wafering

\begin{abstract}
A B S T R A C T
The cutting of silicon wafers using multi-diamond wire sawing is a critical stage in solar cell manufacturing due to brittleness of silicon. Improving the cutting process output requires an in-depth understanding of phenomena associated with cutting parameters. In order to investigate the influence of diamond wire sawing on surface integrity of monocrystalline silicon, a looped diamond wire was used and cutting parameters wire cutting speed, feed rate and wire tension were varied. The surface morphology was observed by scanning electron microscopy. Surface roughness $S_{a}$ was measured with a non-contact profilometer. The brittle-ductile transition was identified by presence of residual phases on sawn surface. A bevel-polishing method was employed to determine the microcrack depth. The results show that with higher feed rate the surface presents deeper and wider craters because of deeper penetration of diamond grain. On increasing wire cutting speed, there were more regions formed in ductile mode. The higher $S_{a}$ values was observed on increasing both feed rate and wire tension, while $\mathrm{S}_{\mathrm{a}}$ decreased with an increase in wire cutting speed. The brittle mode was predominant with an increase in feed rate, resulting in Si-I phase in regions formed in fragile mode. Material removal in ductile mode led to appearance of a-Si phase at high wire cutting speed. No significant effect was observed on increasing wire tension. Subsurface microcracks mainly initiating from bottom of grooves generated by cutting mechanism. The most appropriate set of cutting parameters is the lowest feed rate and wire tension and highest wire cutting speed.
\end{abstract}

\section{Introduction}

Crystalline silicon is the main material used for manufacturing solar cells in the photovoltaic industry, with around $95 \%$ of the solar cells manufactured being based on this material (62\% multi-crystalline silicon and $33 \%$ monocrystalline silicon). Consequently, the photovoltaic industry consumes approximately $90 \%$ of the crystalline silicon produced globally. Crystalline silicon is favored over other semiconductor materials due to its abundance in the earth's crust, comprising approximately $27 \%$ of the minerals present (Ozturk et al., 2018a; Yu et al., 2012). The semiconductor characteristics of crystalline silicon allows a high efficiency to be obtained in power generation.

In order to produce solar cells, crystalline silicon ingots are sawn into wafers with a thickness of $100-180 \mu \mathrm{m}$. Currently, the reciprocating multi-wire sawing (MWS) process is almost exclusively employed in the photovoltaic industry to cut hundreds, and even more than one thousand, wafers from a single crystalline silicon ingot (Möller, 2014). The MWS processes are divided in multi-wire slurry sawing (MWSS) and multi-wire diamond wire sawing (MWDWS). MWSS is a free-abrasive machining method, referred to as the threebody wear mechanism. The cut is performed by a loose silicon carbide (SiC) abrasive dispersed in polyethylene glycol, which is supplied through nozzles over a wire web and carried by gravity to the wire in the sawing channel. MWDWS is performed through a two-body wear mechanism through the interaction of the bonded diamonds on the abrasive wire with the workpiece. MWDWS is widely applied for slicing brittle-hard materials, such as crystalline silicon, sapphire crystals, SiC, stones and optical glass (Gao et al., 2016; Wu, 2016).

Although both sawing processes are widely used in the industrial sector, MWDWS has some advantages over MWSS, including higher material removal rate, better surface quality and, if correctly used, lower machining cost per wafer (Chen et al., 2015; Liu et al., 2017a).

\footnotetext{
*Corresponding author at: Laboratório de Mecânica de Precisão (LMP), Departamento de Engenharia Mecânica - CTC, Universidade Federal de Santa Catarina, Trindade, 88040-900 Florianópolis, SC, Brazil.

E-mail address: erick.cardoso.costa@posgrad.ufsc.br (E.C. Costa).
} 
However, the residual damage introduced by the sawing process, which includes surface roughness, phase transformation and microcracks, remains unavoidable and directly affects the main mechanical, optical and electronic properties of the crystalline silicon wafer (Liu et al., 2017a). Due to the manufacturing of thinner and larger silicon wafers, the damage to the surface integrity, mainly in the form of subsurface microcracks, decreases considerably the fracture strength of the sliced silicon wafer during the post-processing step (e.g., lapping and polishing) as well as the lifespan of the solar module (Liu et al., 2017b; Ozturk et al., 2018b). This generates some concern given that MWDWS is a critical process in the solar cell production chain.

Strategies adopted to reduce the damage at the surface and subsurface of monocrystalline silicon (mono-Si) wafers are associated with the applied cutting conditions, such as wire cutting speed $\left(\mathrm{v}_{\mathrm{c}}\right)$, feed rate $\left(\mathrm{v}_{\mathrm{f}}\right)$ and wire tension $\left(\mathrm{T}_{\text {wire }}\right)$, as well as the characteristics of the wire (Kumar et al., 2016). Many researchers have been trying to understand the macro and micro-kinematics of the sawing process by means of mathematical models and experimental approaches. In the literature, experiments carried on MWDWS are not described in depth. Most researchers have focused on single-diamond wire sawing (DWS). Regarding the surface integrity, Gao et al. (2016) investigated the influence of the cutting parameters $\left(\mathrm{v}_{\mathrm{c}} \leq 2 \mathrm{~m} / \mathrm{s} ; \mathrm{v}_{\mathrm{f}} \leq 0.75 \mathrm{~mm} / \mathrm{min}\right)$ and different cutting fluids on the surface topography, surface roughness, subsurface damage, total thickness variation and bending of the sawn mono-Si. Liu et al. (2017a) evaluated the subsurface microcrack damage of mono-Si induced by DWS with different cutting parameters $\left(\mathrm{v}_{\mathrm{c}} \leq 1.5 \mathrm{~m} / \mathrm{s} ; \mathrm{v}_{\mathrm{f}} \leq 0.75 \mathrm{~mm} / \mathrm{min}\right)$. The authors formulated a mathematical model to describe the microcrack formation based on fracture mechanics theory. Their experimental results validated the proposed model and showed that the depth of the microcracks is mainly influenced by both cutting parameters $\mathrm{v}_{\mathrm{c}}$ and $\mathrm{v}_{\mathrm{f}}$.

Gao et al. (2019) carried out experiments to analyze the influence of the $\mathrm{v}_{\mathrm{f}} / \mathrm{v}_{\mathrm{c}}$ ratio on the brittle-ductile transition in the DWS of mono-Si. On evaluating different cutting parameters $\left(v_{f} \leq 0.75 \mathrm{~mm} / \mathrm{min}\right.$; $\mathrm{v}_{\mathrm{c}} \leq 2 \mathrm{~m} / \mathrm{s}$ ) they observed that the $\mathrm{v}_{\mathrm{f}} / \mathrm{v}_{\mathrm{c}}$ ratio has a significant influence on the material removal mechanism. Pala et al. (2020) introduced a method for the characterization of the surface morphology by image processing and they showed that both $\mathrm{v}_{\mathrm{c}}$ and $\mathrm{v}_{\mathrm{f}}$ influence the percentage of ductility and fragility of the sawn surface of mono-Si. However, the authors carried out experiments employing kinematics similar to that of grinding and the material removal mechanism was not validated by the residual crystalline phase. Kayabasi et al. (2017) investigated the effects of variations in the wire cutting speed $\left(\mathrm{v}_{\mathrm{c}} \leq 4.5 \mathrm{~m} / \mathrm{s}\right)$, feed rate $\left(\mathrm{v}_{\mathrm{f}} \leq 2 \mathrm{~mm} / \mathrm{min}\right)$ and oil/water emulsion ratio ( $100 \%$ and $30 \%$ oil) on the surface roughness of sawn mono-Si wafers. An artificial neural network (ANN) was accommodated to predict the surface roughness parameter $R_{a}$ using the data obtained from the DWS cutting experiments. Ozturk et al. (2018b) used regression models to optimize the surface roughness (parameters $\mathrm{R}_{\mathrm{a}}, \mathrm{R}_{\mathrm{q}}$ and $\mathrm{R}_{\mathrm{z}}$ ) of mono-Si specimens cut with a diamond wire. They employed a wire cutting speed of $\mathrm{v}_{\mathrm{c}} \leq 4.5 \mathrm{~m} / \mathrm{s}$ and feed rate of $\mathrm{v}_{\mathrm{f}} \leq 1 \mathrm{~mm} / \mathrm{min}$.

The aforementioned authors provided valuable results, but an effective correlation between the cutting parameters and surface integrity of mono-Si wafers cut by DWS has not yet been established. Furthermore, the wire cutting speed of $\mathrm{v}_{\mathrm{c}}=20 \mathrm{~m} / \mathrm{s}$ is widely employed in the wafering industry; however, few experiments have been conducted using a wire cutting speed close that value. Kumar et al. (2016) analyzed the wear of diamond wires for a wire cutting speed of $\mathrm{v}_{\mathrm{c}}=18 \mathrm{~m} / \mathrm{s}$. Knoblauch et al. (2018) carried out experiments using an endless wire saw test rig to analyze the progression of wear in the diamond sawing of mono-Si, with a wire cutting speed of $\mathrm{v}_{\mathrm{c}}=13.7 \mathrm{~m} / \mathrm{s}$ and constant feed force of $F_{f}=3.1 \pm 0.6$ N. Suzuki et al. (2017) investigated the effect of the diamond grain size and number of sawing cycles on the surface roughness and subsurface damage using a wire cutting speed of $\mathrm{v}_{\mathrm{c}}=29 \mathrm{~m} / \mathrm{s}$. However, although these authors applied wire cutting speeds close to those used in industrial applications, the influence of the cutting conditions on the surface integrity was not evaluated. A previous investigation revealed that there is a close relationship between the microcrack depth and surface roughness in terms of the parameter $\mathrm{R}_{\mathrm{z}}$, and that the surface and subsurface integrity is strongly influenced by variations in the cutting parameters when silicon is cut using the diamond wire sawing process (Costa et al., 2019).

In order to contribute to the diamond wire sawing (DWS) technology and better understanding the material removal phenomena involved in the sawing of mono-Si wafers, the effects of the main cutting parameters $\left(\mathrm{v}_{\mathrm{c}}, \mathrm{v}_{\mathrm{f}}\right.$ and $\left.\mathrm{T}_{\text {wire }}\right)$ on the surface integrity of sawn mono-Si workpieces were investigated. This paper reports an experimental study on the characteristic of the brittle-ductile transition of the sawn surface of mono-Si and discusses the results considering the surface morphology, surface roughness, phase transformation and microcracks in the subsurface region. The present paper is an important study for the researches aiming directly increase the silicon wafer quality in photovoltaic applications.

\section{Experimental procedure}

\subsection{Experimental setup and design of experiments}

The experiments were carried out on the endless wire saw developed by Knoblauch et al. (2017a), shown in Fig. 1. In contrast to the industrial DWS machines, in this study a single-electroplated diamond wire in the shape of a loop was employed. Thus, instead of using a few thousand meters of wire for a multi-cut, single cuts were performed using only around a 1-meter segment of diamond wire. The ends of the industrial diamond wire segment were butt-welded on a welding device developed by Knoblauch et al. (2017b). After the loop shape had been obtained, the diamond wire was wrapped around two Teflon ${ }^{\circledR}$ discs and moved by the driven rotary axis with constant rotation to perform the cut with a constant wire cutting speed $\left(\mathrm{v}_{\mathrm{c}}\right)$.

The test rig slides and rotatory bearings (X, Y, Z, a and $\mathrm{a}^{\prime}$ ) are based on aerostatic slides/bearings, which ensure low friction on them (see Fig. 1). This ensures that the applied forces are correspondingly applied in the cutting zone (no stick-slip effect on the input variables) and allows the cuts to be controlled with constant wire tension. The cut is performed by the endless diamond wire wrapped around two Teflon ${ }^{\circledR}$ pulleys, mounted on the front side of the two rotatory spindles. An electric AC motor, controlled by a frequency inverter, drives the main spindle. The maximum cutting speed of the wire is $\mathrm{v}_{c}=26 \mathrm{~m} / \mathrm{s}$. The wire tension $\left(\mathrm{T}_{\text {wire }}\right)$ is set by the air pressure on a pneumatic cylinder and controlled by the deflection of a spiral spring. The vertical feed movement is driven by a step motor/ball bearing system. The minimum feed rate is $v_{f}=0.08 \mathrm{~mm} / \mathrm{min}$ and the value can be set using the control interface. The width of the mono-Si specimen slices is manually set on the Z-axis by a micrometer adjustment screw.

The diamond wire used in this study is an industrial Ni electroplated diamond wire, manufactured by Norton Saint-Gobain Abrasives, with an outer diameter $\emptyset_{\mathrm{OD}}=350 \mu \mathrm{m}$, wire core diameter of $250 \mu \mathrm{m}$ and diamond grain size of $30-45 \mu \mathrm{m}$. The diamond grains are distributed randomly over the wire surface and bonded by a nickel (Ni) layer (Fig. 2).

Considering its widespread use in the manufacturing of solar cells, mono-Si was employed for this study, in the form of rectangular test specimens with dimensions of $25 \mathrm{~mm} \times 50 \mathrm{~mm} \times 7 \mathrm{~mm}$ (Fig. 3a). The specimens were sawn into slices $(25 \mathrm{~mm} \times 1 \mathrm{~mm} \times 7 \mathrm{~mm})$ with $1 \mathrm{~mm}$ thickness, parallel to the crystallographic plane (100), according to the Miller index (see Fig. 3b). The cutting direction in the kerf is normal to the crystallographic plane (010).

A full factorial design of experiments (DOE) was performed and experiments were carried out using the cutting parameters $\mathrm{v}_{\mathrm{c}}$ and $\mathrm{v}_{\mathrm{f}}$ at three different levels (low, medium and high), and $\mathrm{T}_{\text {wire }}$ at two levels (low and high), as indicated in Table 1. Each experiment was performed three times. 


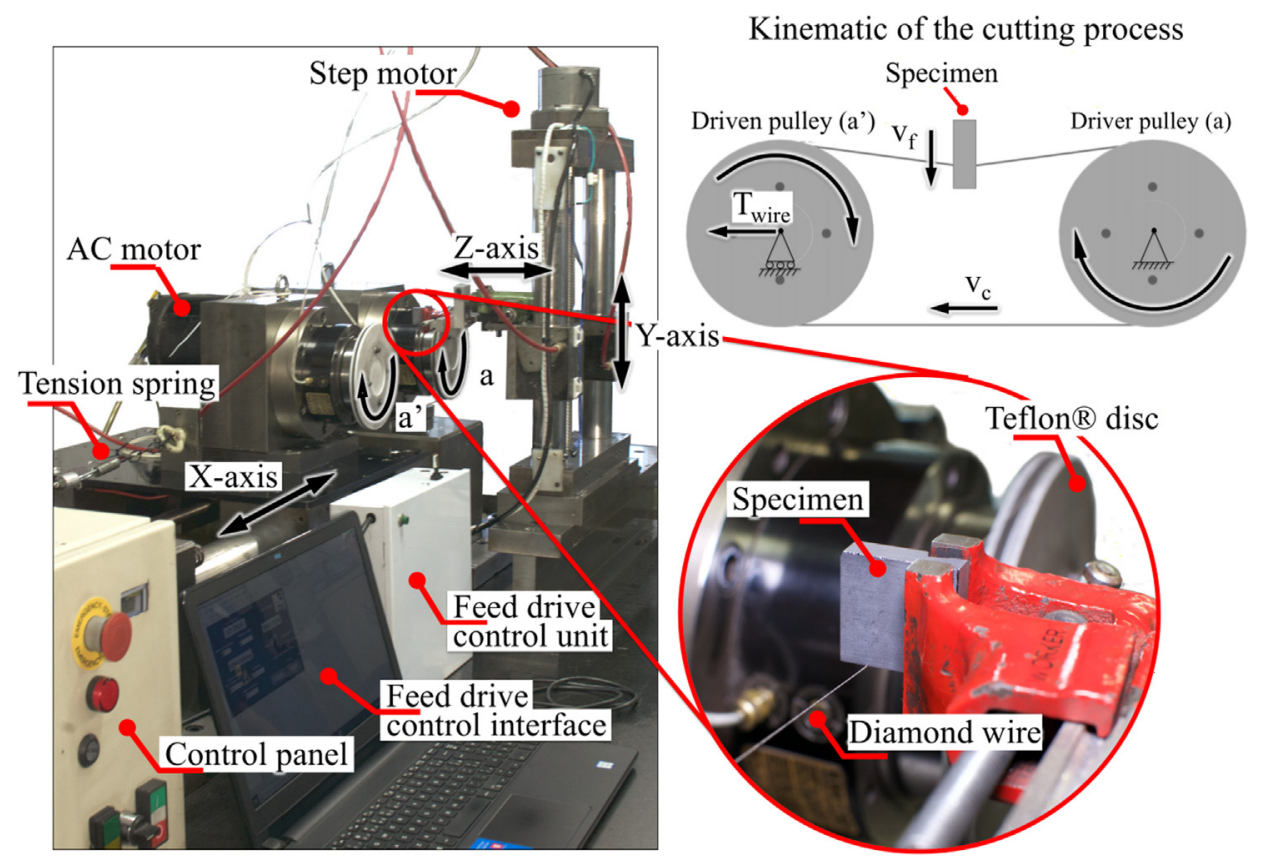

Fig. 1. Endless wire saw test rig.

For each single sawing experiment, a new (unworn) diamond wire was employed to minimize the effect of the wear of the diamond wire on the workpiece surface integrity. The cuts were performed dry. The sawn specimens were submitted to surface integrity analysis, based on the following techniques: surface morphology analysis by scanning electron microscopy (SEM), surface roughness analysis, micro-Raman spectroscopy and subsurface damage analysis (details are given in Section 2.2).

A statistical evaluation was carried out to quantify the influence of the cutting parameters $\mathrm{v}_{\mathrm{c}}, \mathrm{v}_{\mathrm{f}}$ and $\mathrm{T}_{\text {wire }}$ on the surface integrity. Analysis of variance (ANOVA), with a 95\% confidence interval and confidence level of $\alpha=0.05$, was performed to determine the effects of the factors, the divergence percentages and the p-values, as described by Montgomery and Runger (2014).

\subsection{Surface integrity analysis}

\subsubsection{Surface morphology}

The surface morphology characteristics of the mono-Si specimens, sawn applying different cutting parameters, were determined by SEM (Hitachi TM-3030 microscope). The SEM micrographs allow the damage caused to the surface by the sawing process to be observed, which provides information on the material removal mechanisms that act during the cutting process.

\subsubsection{Surface roughness}

The surface roughness of the sawn specimens is influenced by the characteristics of the diamond wire and the distribution of the diamond grains on the wire. Therefore, the surface roughness was measured using an optical non-contact profilometer (Zygo NewView 7300). Three-dimensional images of the surface topography were generated using the software MetroPro ${ }^{\circledR}$, version 8.1.5. For each sawn specimen, images of three different regions, with an area of $1 \mathrm{~mm}^{2}$, were acquired in order to obtain an average value for the measured surface roughness. The software MountainsMap Universal ${ }^{\circledR} 7.1$ was used to process the measurement data, as recommended in ISO 16610-61, and the surface roughness parameter $\mathrm{S}_{\mathrm{a}}$ (arithmetic average height) was extracted according to ISO 25178-2. As a result, for the three specimens sawn under the same cutting conditions, an arithmetic mean value of $S_{a}$ was determined.

\subsubsection{Raman spectroscopy}

Raman spectroscopy was used to identify the presence of different crystalline phases on the sawn surface. The sawn specimens were

b)
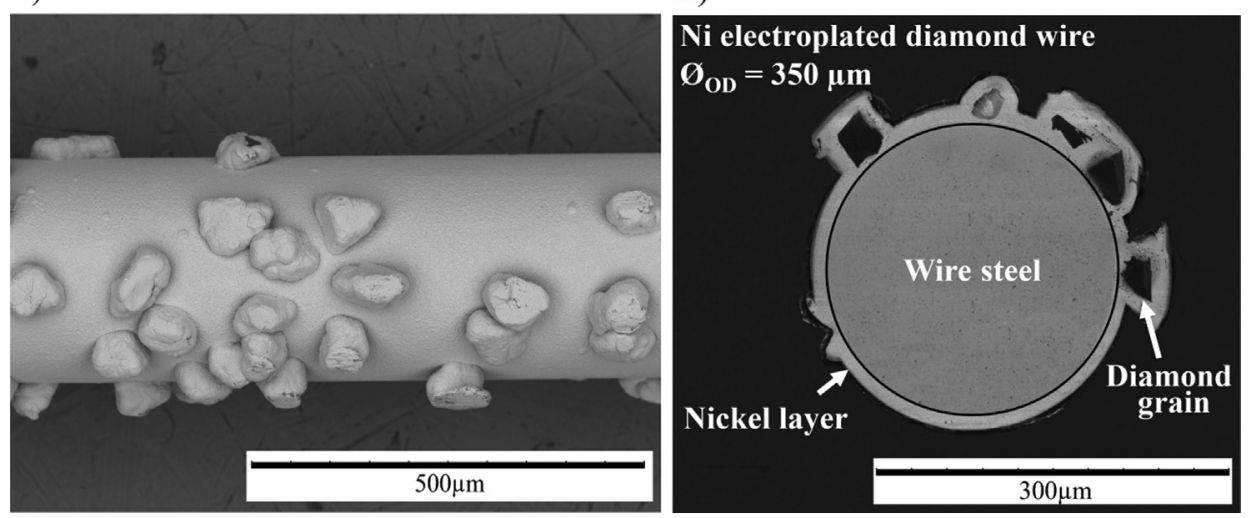

Fig. 2. SEM images of the Ni electroplated diamond wire: (a) surface and (b) cross-section. 
a)

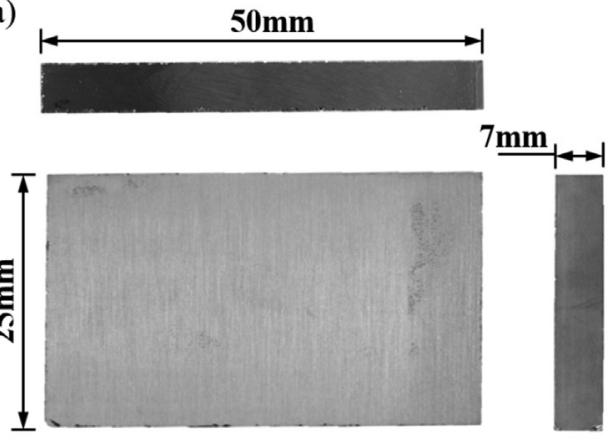

b)

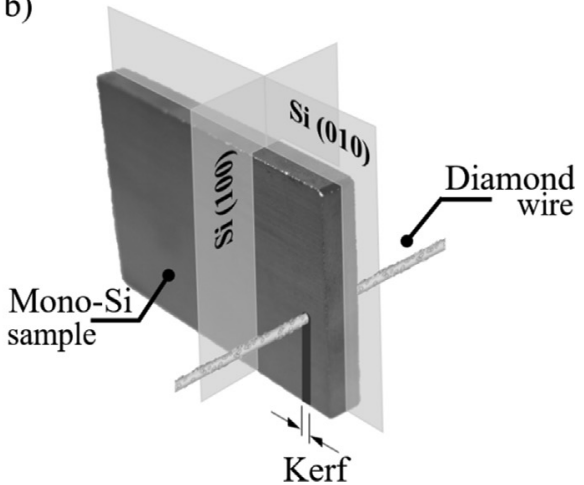

Fig. 3. Mono-Si test specimen: (a) dimensions and (b) crystallographic planes in detail.

Table 1

List of cutting parameters used in the cutting experiments.

\begin{tabular}{llll}
\hline Test & $\mathrm{v}_{\mathrm{c}}(\mathrm{m} / \mathrm{s})$ & $\mathrm{v}_{\mathrm{f}}(\mathrm{mm} / \mathrm{min})$ & $\mathrm{T}_{\text {wire }}(\mathrm{N})$ \\
\hline 1 & 10 & 20 & 20 \\
2 & 10 & 30 & 20 \\
3 & 10 & 40 & 20 \\
4 & 15 & 20 & 20 \\
5 & 15 & 30 & 20 \\
6 & 15 & 40 & 20 \\
7 & 20 & 20 & 20 \\
8 & 20 & 30 & 20 \\
9 & 20 & 40 & 20 \\
10 & 10 & 20 & 30 \\
11 & 10 & 30 & 30 \\
12 & 10 & 40 & 30 \\
13 & 15 & 20 & 30 \\
14 & 15 & 30 & 30 \\
15 & 15 & 40 & 30 \\
16 & 20 & 20 & 30 \\
17 & 20 & 30 & 30 \\
18 & 20 & 40 & 30 \\
\hline
\end{tabular}

analyzed using a Renishaw ${ }^{\circledast}$ inVia micro-Raman microscope that operates with an Ar-laser (wavelength of $514.2 \mathrm{~nm}$ ). The focal point of the laser was set on the sawn surface with an optical magnification lens (500x), and the Raman spectra were acquired through an accumulation of $10 \mathrm{~s}$ with three replicates in the bandwidth region of $200-700 \mathrm{~cm}^{-1}$ using the software Wire $3.4^{\circledR}$.

Based on considerations made by Gao et al. (2019) regarding the influence of the r-ratio $v_{f} / v_{c}$ (dimensionless) on the material removal mechanism in DWS, four mono-Si specimens sawn with different r-ratios were analyzed. In each case, the analysis was performed twice and the two regions investigated showed evidence of (i) the brittle mode and (ii) the ductile mode of material removal. This step was carried out in order to confirm the presence of brittle material removal and the progression of ductile material removal in the region by detecting the residual crystalline phases on the sawn surface corresponding to each material removal mechanism.

\subsubsection{Subsurface damage}

Based on the ASTM F 950-02 standard, an embedding and bevelpolishing method was employed to analyze the depth of subsurface damage caused by the cutting of mono-Si specimens (see Fig. 4). The mono-Si specimens sawn by DWS were embedded in acrylic resin with a tilt angle $\alpha\left({ }^{\circ}\right)$, after being ground and polished. The depth of the microcrack damage observed on the polished surface was obtained under the bevel angle $\alpha$, which permitted the geometric determination of the arithmetic mean depth of the microcracks for each specimen analyzed.

\section{Results and discussion}

\subsection{Surface morphology}

Figs. 5 and 6 shows the SEM micrographs of the sawn surface of the mono-Si specimens cut with a wire tension of $\mathrm{T}_{\text {wire }}=20 \mathrm{~N}$ and $\mathrm{T}_{\text {wire }}=30 \mathrm{~N}$, respectively. The sawn surfaces are composed of parallel and oriented grooves that follow the direction of the effective sawing movement, as also noted by Bidiville et al. (2009) and Yu et al. (2012). Each SEM image shows areas with craters, microcracks and pitting, which are formed under the fragile (brittle) regime, and smooth areas characterized by the presence of parallel and oriented grooves, formed under the ductile regime. On comparing the nine cutting conditions evaluated for each $\mathrm{T}_{\text {wire }}$, it can be observed that the proportion of each cutting regime varies with a variation in the cutting parameters $\left(\mathrm{v}_{\mathrm{c}}\right.$ and $v_{f}$ ). This is in agreement with the results of Gao et al. (2019), although the respective values of $v_{c}$ and $v_{f}$ were much lower than the parameters used in this study.

On applying a high $\mathrm{v}_{\mathrm{f}}$, the material removal occurs predominately through the fragile regime. Due to the penetration of the most protruded diamond grains into the mono-Si surface, corresponding to a high average undeformed chip thicknesses $\left(\mathrm{h}_{\mathrm{cu}}\right)$, on exceeding a critical value $\left(\mathrm{h}_{\mathrm{cu}, \text { crit }}\right)$, plastic deformation gives way to microcrack formation and propagation. A further increase in $\mathrm{v}_{\mathrm{f}}$ induces surface formation predominantly with fragile fracture as the main material removal mechanism. According to Liu et al. (2017b), an increase in $\mathrm{v}_{\mathrm{f}}$ leads to a higher number of active diamond grains that effectively are assuming the cut, with material removed under the brittle regime, and this situation progresses with increasing $\mathrm{v}_{\mathrm{f}}$ while maintaining $\mathrm{v}_{\mathrm{c}}$ and $\mathrm{T}_{\text {wire }}$ constant.

On the other hand, increasing $v_{c}$, while maintaining the same conditions described for the variation in $\mathrm{v}_{\mathrm{f}}$ and $\mathrm{T}_{\text {wire }}$, resulted in a reduction in the microcracks and craters on the sawn surface. The diamond grains present different degrees of protrusion and their shapes vary, which leads to a difference in the stress state acting at point of grain/material contact. As a consequence, the sawn surface presents regions with evidence of mixed ductile and fragile modes, as seen in the SEM micrographs in Figs. 5 and 6. Considering a fixed range of diamond grain protrusion and that all diamond grains are in contact with the surface of the mono-Si specimen, an increase in $\mathrm{v}_{\mathrm{c}}$ would increase the engagement frequency of the diamond grains on the mono-Si specimen along the sawing line, leading to a decrease in $\mathrm{h}_{\mathrm{cu}}$. As a result, more kinematic cutting edges will engage and contribute to the removal of ductile material, as reported by Liu et al. (2017b) and Chung and Le (2015). This change from brittle to ductile mode in the material removal mechanism, resulting in surfaces with more regions that are free of fractures associated with the fragile mode.

All sawn surfaces obtained in these experiments exhibited both ductile and fragile material removal modes. The ductile regime was 
Subsurface of
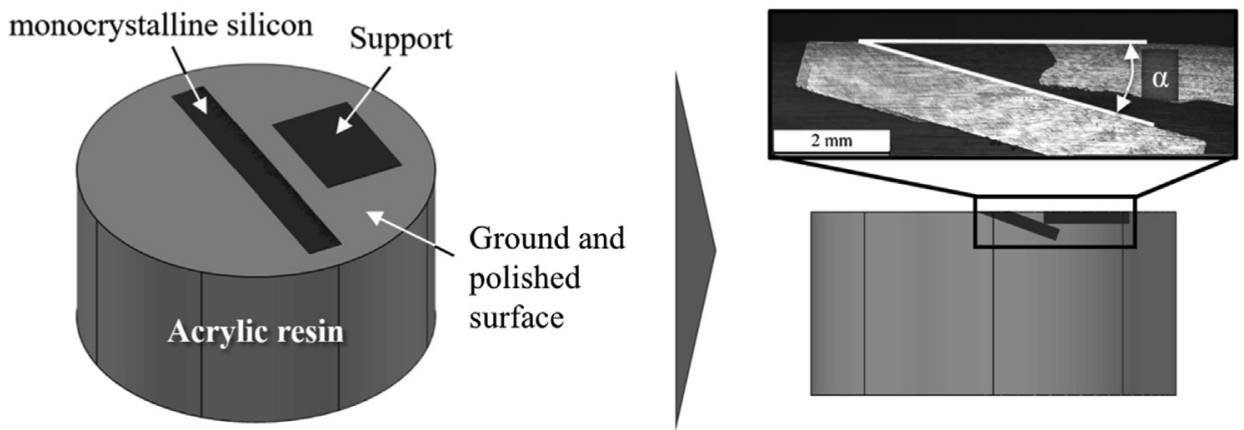

Fig. 4. Schematic diagram of embedded and bevel-polished specimen.

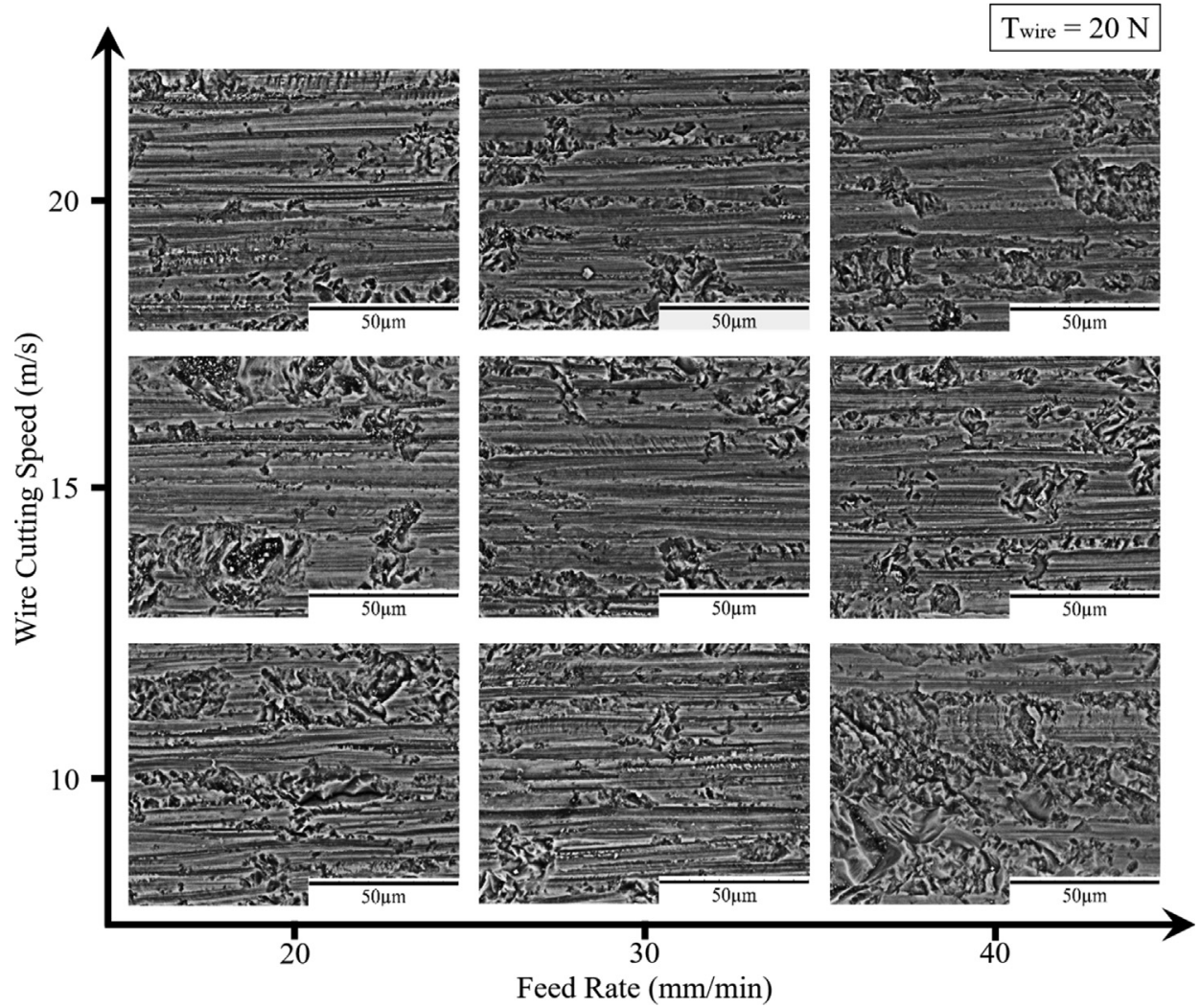

Fig. 5. SEM micrographs showing the surface morphology of mono-Si specimens sawn under a wire tension of $20 \mathrm{~N}$.

dominant for the combination of highest $\mathrm{v}_{\mathrm{c}}$ and lowest $\mathrm{v}_{\mathrm{f}}$. On comparing the results in Figs. 5 and 6, although the wire tension increases, the sawn surfaces under both wire tension conditions presented similar morphological characteristics, indicating a mixture of fragile and ductile modes as the material removal mechanism. However, the fragile behavior observed in the SEM micrographs in Fig. 5 is slightly more accentuated when the $T_{\text {wire }}$ is increased from 20 to $30 \mathrm{~N}$, as can be seen in Fig. 6.

\subsection{Surface roughness}

The surface roughness is influenced by variations in $\mathrm{v}_{\mathrm{f}}, \mathrm{v}_{\mathrm{c}}$ and $\mathrm{T}_{\text {wire. }}$ Fig. 7 shows the results for the variation in the arithmetic mean value for the surface roughness parameter $S_{a}$ for the mono-Si specimens sawn under different cutting conditions. It can be observed that the mean value increases with an increase in $v_{f}$ and decreases with high $v_{c}$, for both $\mathrm{T}_{\text {wire }}$ values. This can be explained by the combination of brittle/ ductile regimes during the chip formation. At high $\mathrm{v}_{\mathrm{f}}$ and low $\mathrm{v}_{\mathrm{c}}$ the sawn surface is formed by extensive fractured regions, observed in the form of craters (Jackson and Davim, 2011). According to Klocke (2008), fragile fractures can be attributed to an increase in the frictional force per grain and, consequently, higher $\mathrm{h}_{\mathrm{cu}}$ due to an increase in the penetration of the diamond grains. Therefore, as described by Bifano et al. (1991), the penetration depth has a significant influence on the fragile fracture formation, resulting in the presence of more craters and pitting on the sawn surface.

The graphs in Fig. 7 show that the surface roughness parameter $S_{a}$ presented a slight reduction with an increase in $\mathrm{v}_{\mathrm{c}}$ from 10 to $20 \mathrm{~m} / \mathrm{s}$. According to Marinescu et al. (2015), this behavior is associated with a reduction in $\mathrm{h}_{\mathrm{cu}}$ as a consequence of the higher engagement frequency of the diamond grains on surface of the specimen. A lower penetration depth of the grains favors material removal in the ductile regime, reducing the surface roughness, since more damage-free regions are generated during the surface formation.

Higher $S_{a}$ values were obtained for the highest $v_{f}$ and lowest $v_{c}$ for both wire tensions, as seen in Fig. $7 \mathrm{a}$ and $7 \mathrm{~b}$. An increase in $\mathrm{T}_{\text {wire }}$ caused 


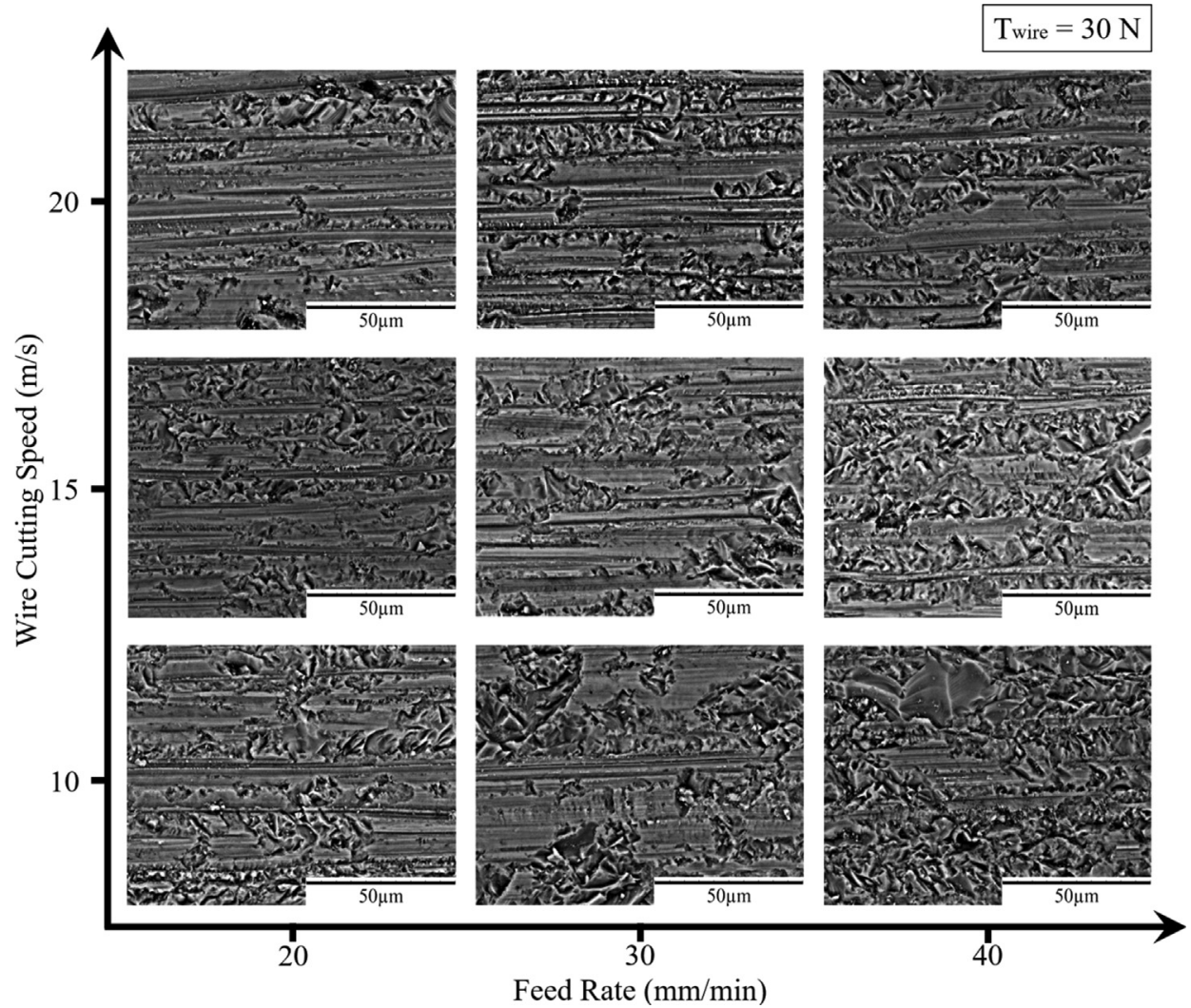

Fig. 6. SEM micrographs showing the surface morphology of mono-Si specimens sawn under a wire tension of $30 \mathrm{~N}$.

an increase in the surface roughness with notably higher values of $S_{a}$. An increase in the wire tension from 20 to $30 \mathrm{~N}$ reduced significantly the wire deflection during the cutting process. Considering the kinematics of the cutting process shown schematically in Fig. 8, it can be seen that in the initial stage (see Fig. 8a) there is no contact between the wire and the specimen, and the cutting wire movement remains perpendicular to the feed rate $\left(\mathrm{v}_{\mathrm{f}}\right)$. With the feed movement of the specimen against the wire, a deflection effect was observed, as shown in Fig. 8b. Although the chip removal mechanism of the diamond wire sawing is similar to that of the grinding process, the diamond wire is considered a flexible cutting tool. This characteristic generates a displacement of the free wire length in the form of a wire bow with an angle $(\Phi)$. In comparison to the initial stage (Stage 1), the diamond wire will then be in a new vertical position (Stage 2) caused by its deflection, as shown in Fig. 8c.

Applying a wire tension $T_{2}>T_{1}$, for same condition of $v_{c}$ and $v_{f}$, result in an angle $\Phi_{2}$ smaller than the wire bow angle $\left(\Phi_{1}\right)$ generated under a wire tension $T_{1}$, as shown in Fig. $8 \mathrm{~d}$. In the experiment was observed that an increase in $\mathrm{T}_{\text {wire }}$ from 20 to $30 \mathrm{~N}$ reduces the deflection effect and the wire bow angle $(\Phi)$ becomes smaller, resisting the force perpendicular to the cutting movement direction (component of feed force). As a results, there is a significant increase in the material removal rate due to the higher $\mathrm{h}_{\mathrm{cu}}$, compared to that at $\mathrm{T}_{\text {wire }}=20 \mathrm{~N}$. In this regard, it can be stated that the higher material removal rate is the main factor that led to higher $S_{a}$ values when the $T_{\text {wire }}$ was varied from 20 to $30 \mathrm{~N}$.

The behavior of the parameter $S_{a}$ obtained from the surface roughness measurements (see Fig. 7) are consistent with the surface a)

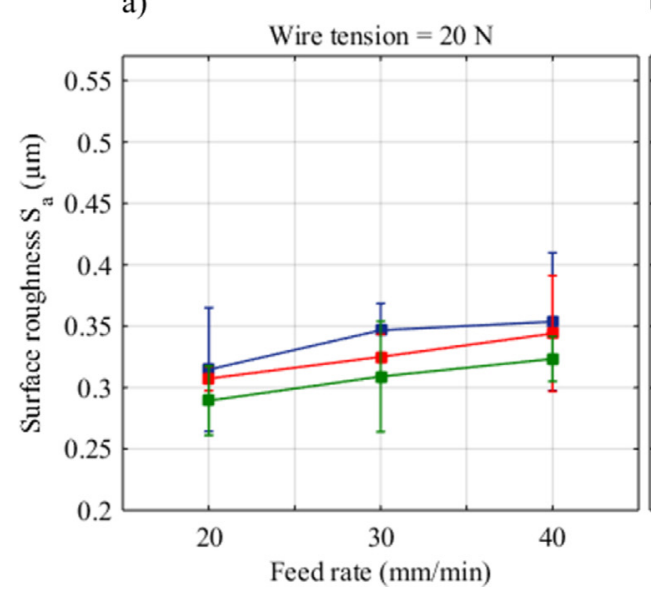

b)

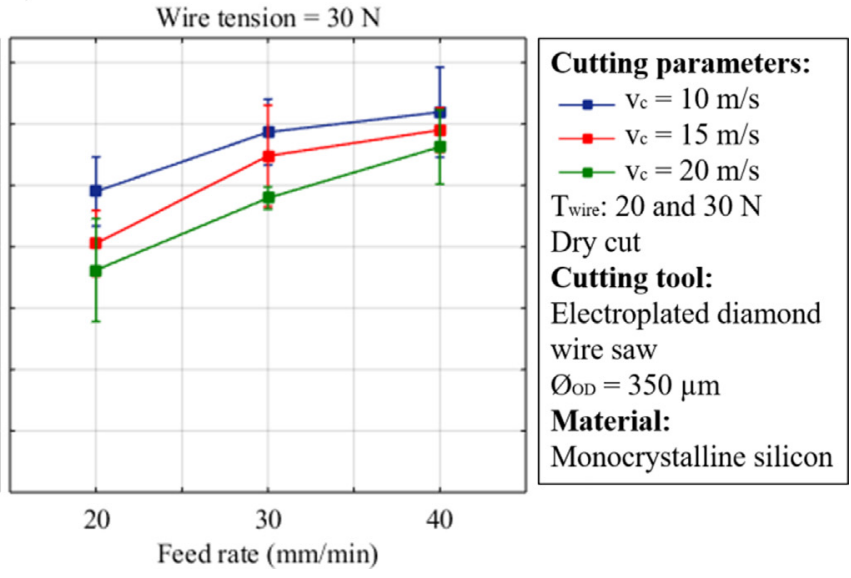

Fig. 7. Surface roughness of the mono-Si specimens with variations in the cutting parameters. 
a)

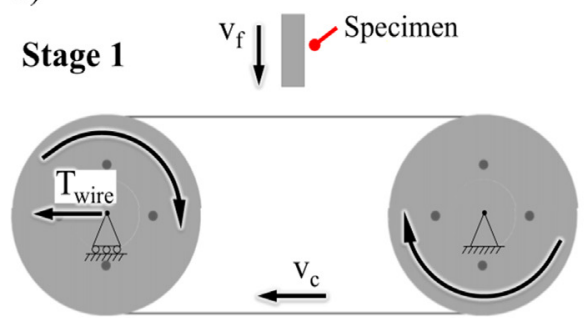

c)

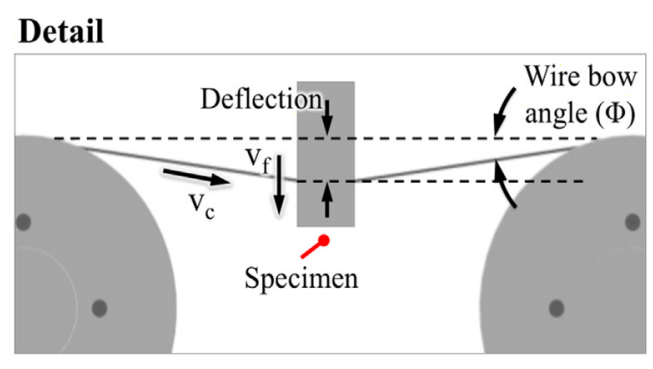

b)

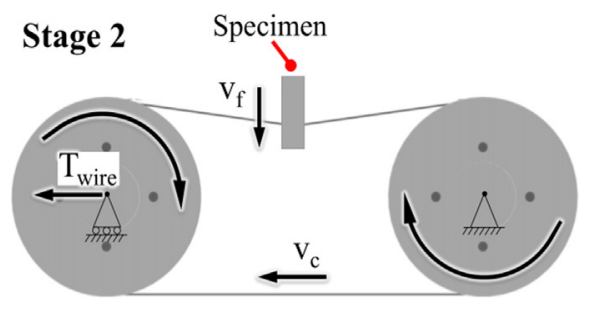

d)

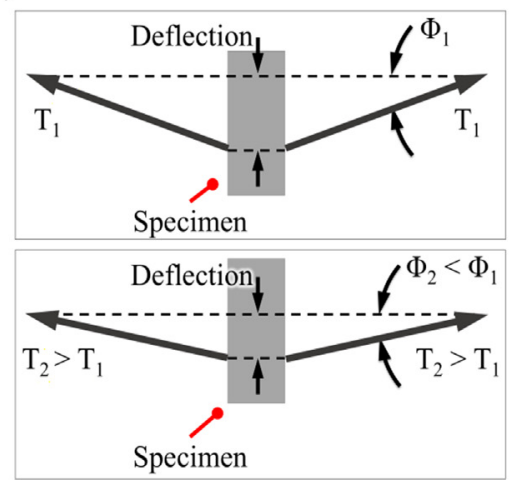

Fig. 8. Influence of the wire tension on the kinematic of the cutting process.

morphology of the mono-Si specimen sawn shown in Figs. 5 and 6. It can be observed that the sawn surfaces with more fragile fractures have the highest $S_{a}$ values, whereas for the sawn mono-Si specimens with a predominance of the ductile chip forming mechanism the variation in the arithmetic mean of the $S_{a}$ values is significantly lower.

According to the ANOVA analysis, an increase in $\mathrm{v}_{\mathrm{c}}$ decreased the surface roughness parameter $S_{a}$ by up to $10.2 \%$ (p-value $=0.000894$ ). On the other hand, there was an increase in the $S_{a}$ values on increasing both cutting parameters $\mathrm{v}_{\mathrm{f}}$ and $\mathrm{T}_{\text {wire }}$. With an increase in $\mathrm{v}_{\mathrm{f}}$, the value of $\mathrm{S}_{\mathrm{a}}$ increased by up to $15.6 \%$ (p-value $=0.000003$ ). In the case of $\mathrm{T}_{\text {wire, }}$, an increase from 20 to $30 \mathrm{~N}$ resulted in an increase in the $S_{a}$ values by up to $34.3 \%$ (p-value $=0.000000$ ). Based on the ANOVA results, it can be stated that variations in the cutting parameters $\mathrm{v}_{\mathrm{c}}, \mathrm{v}_{\mathrm{f}}$ and $\mathrm{T}_{\text {wire }}$ had a significant effect on the surface roughness of the mono-Si specimens, since the p-values remained at $<0.05$ for all factors analyzed.

\subsection{Raman spectroscopy}

The SEM micrographs on the left side of Fig. 9 show the regions analyzed by Raman spectroscopy for the specimens sawn applying different cutting conditions, considering the r-ratio $\left(\mathrm{v}_{\mathrm{f}} / \mathrm{v}_{\mathrm{c}}\right)$. The image in Fig. 9a shows a surface composed of extensive and deep craters, which indicates that there was a predominance of the fragile regime as the material removal mechanism. According to Bifano et al. (1991), this characteristic suggests that $h_{c u}$ exceeded $h_{c u, c r i t}$, which means that the fracture resistance limit is reached before plastic deformation occurs, resulting in the material removal by fragile fracture. Therefore, the surface was formed through crack propagation resulting in the presence of craters on the sawn surface. The analysis of the phase transformation was based on the Raman spectra for the sawn surfaces, also shown in Fig. 9. The spectra in Fig. 9a show a single peak at $523 \mathrm{~cm}^{-1}$, corresponding to the cubic diamond phase structure (Si-I). According to $\mathrm{Wu}$ and Melkote (2012), the Si-I phase is present in regions where the material removal mechanism was predominantly the fragile regime. Therefore, as the chip formation and removal was mainly by crack propagation, the pure crystal silicon (Si-I phase) becomes exposed.

The sawn surfaces shown in Fig. 9b also exhibit a predominance of the fragile regime, evidenced by craters and a few damage-free spots.
The Raman spectra in Fig. 9b show three new peaks at $349 \mathrm{~cm}^{-1}$ (Si-XII phase), $433 \mathrm{~cm}^{-1}$ (Si-III phase), and $469 \mathrm{~cm}^{-1}$ (a-Si phase). The plasticity of the crystalline silicon have as primary mechanism the highpressure phase transformation that cause brittle-ductile transition. The presence of these residual crystalline phases suggests that the Si-I phase underwent a phase transformation to the metallic phase Si-II due to the action of the grain/material contact pressure, which permits plastic deformation during chip formation. This is a result of the increase in $v_{c}$ from $10 \mathrm{~m} / \mathrm{s}$ to $15 \mathrm{~m} / \mathrm{s}$, which induces a lower $h_{\text {cu }}$ value due to the highest engagement frequency of the diamond grain on the surface of the mono-Si. It can be stated that a value of $\mathrm{v}_{\mathrm{c}}=15 \mathrm{~m} / \mathrm{s}$ allows the phase transformation of Si-I to metastable Si-II which can assume the crystalline and amorphous phases. The residual phases observed are formed by different unloading conditions: Si-XII and Si-III phases are attributed to a slow unloading rate and the a-Si phase is a result of a high unloading rate. These results can be attributed to the different levels of protrusion and shapes of the diamond grain, which lead to variations in the stress states underneath the grain/material contact point. Although there are different residual phases, the Si-XII, Si-III and a-Si phases occur due to the shear-induced phase transformation of the mono-Si during chip removal in the ductile regime.

The SEM micrographs in Fig. 9c and 9d show the sawn surface of the mono-Si specimen obtained with r-ratios of $2.5 \times 10^{-5}$ and $1.6 \times 10^{-5}$, respectively. The characteristic predominance of a smooth surface can be observed with oriented, parallel and damage-free grooves, the socalled saw mark grooves. This suggests that on increasing $\mathrm{v}_{\mathrm{c}}$ and decreasing $\mathrm{v}_{\mathrm{f}}$ the mono-Si cutting occurs predominantly in the ductile regime, although the a few regions with craters are still presented, which indicates that part of the material was removed in the fragile regime due to different degrees of protrusion and shape of the diamond grains as well as lateral vibrations of the diamond wire.

The damage-free grooves correspond to the material removal mechanism in the ductile regime, as can be observed by the appearance of a secondary phase of silicon due to the phase transformation phenomenon. This phase transformation from Si-I to Si-II with $\beta$-tin structure at high-pressure phase transformation results in the formation of an amorphous and metastable phase, which is a consequence of the ductile behavior of the mono-Si during plastic deformation. Under the 
a)

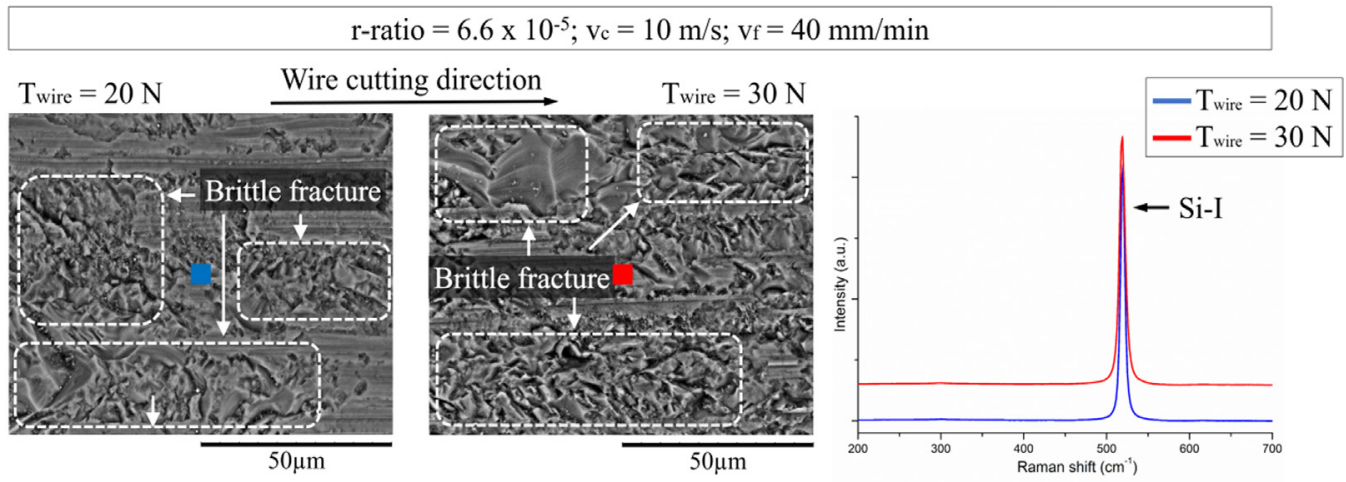

b) r-ratio $=4.4 \times 10^{-5} ; \mathrm{vc}_{\mathrm{c}}=15 \mathrm{~m} / \mathrm{s} ; \mathrm{vf}=40 \mathrm{~mm} / \mathrm{min}$
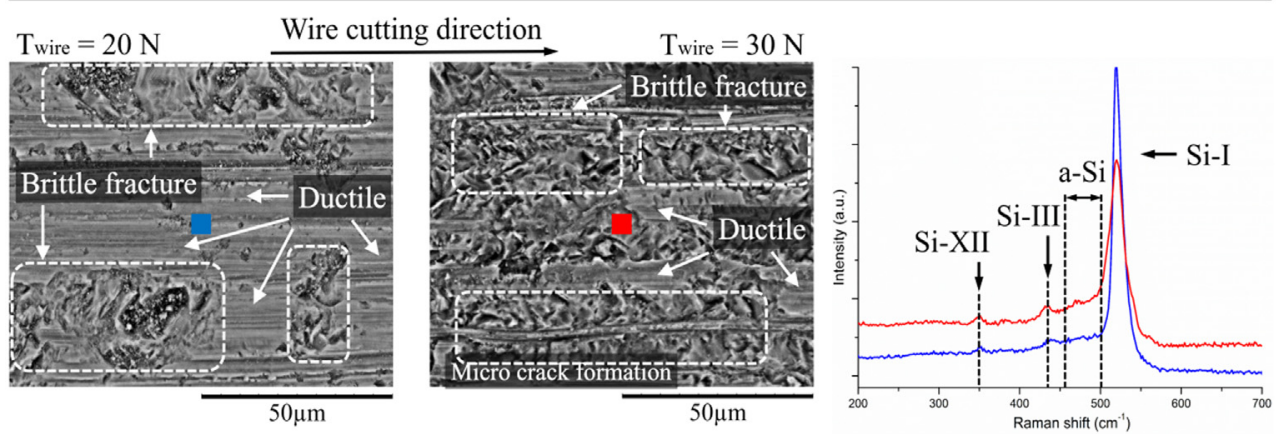

c) r-ratio $=2.5 \times 10^{-5} ; \mathrm{vc}=20 \mathrm{~m} / \mathrm{s} ; \mathrm{vf}=30 \mathrm{~mm} / \mathrm{min}$

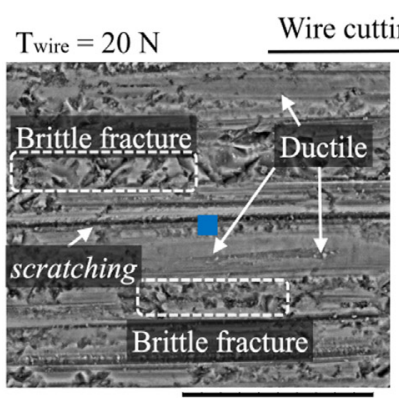

$50 \mu \mathrm{m}$
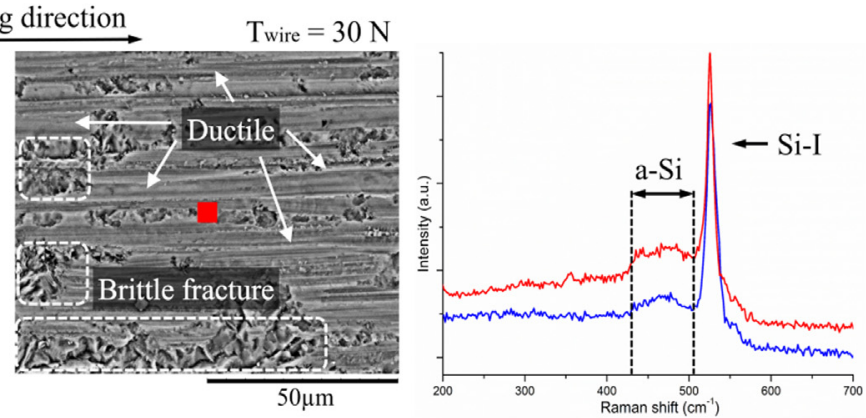

d)

$$
\text { r-ratio }=1.6 \times 10^{-5} ; \mathrm{vc}=20 \mathrm{~m} / \mathrm{s} ; \mathrm{vf}=20 \mathrm{~mm} / \mathrm{min}
$$
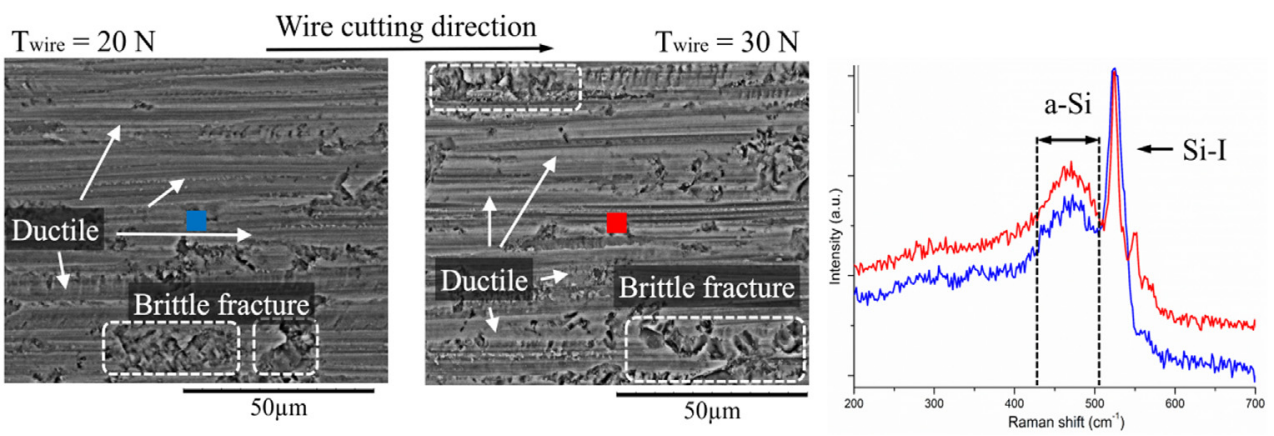

Fig. 9. SEM micrographs and respective Raman spectra of sawn surfaces obtained with variations in the cutting parameters.

ductile cutting conditions, it is possible to avoid microcrack initiation, since the mono-Si behaves as a ductile material during chip formation and removal. This is evidenced by the Raman spectra in Fig. 9c and 9d, where the bandwidth of the amorphous phase (a-Si) has a peak at $475 \mathrm{~cm}^{-1}$. The presence of the a-Si phase is consistent with the ductile removal of mono-Si during the cutting, which is caused by grains that cut with $\mathrm{h}_{\mathrm{cu}}$ below the critical value $\left(\mathrm{h}_{\mathrm{cu}, \mathrm{crit}}\right)$ that produce a microcutting as well as by grains that are only generates ploughing over the workpiece surface.

Wang et al. (2020) reported that the phase transformation of the (100) mono-Si during high-speed scratching shows several residual phases as a consequence of the ductile mode of the material. The authors evidenced that at high-speed scratching between $10 \mathrm{~m} / \mathrm{s}$ and $25 \mathrm{~m} / \mathrm{s}$ there is an exponential increase in the intensity of the a-Si and Si-IV peaks on the Raman spectra, caused mainly by a higher unloading rate. Based on this finding, along with the results obtained during the 
a) $\mathrm{vc}_{\mathrm{c}}=10 \mathrm{~m} / \mathrm{s} ; \mathrm{vf}=20 \mathrm{~mm} / \mathrm{min}$

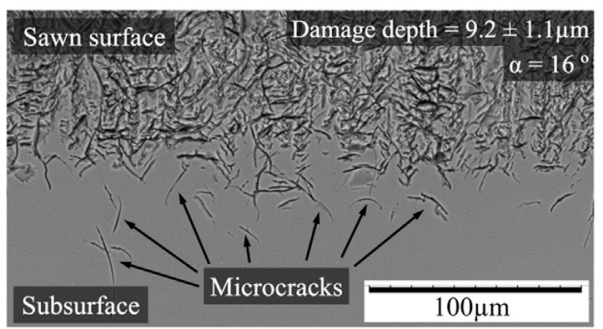

c) $\mathrm{vc}_{\mathrm{c}}=15 \mathrm{~m} / \mathrm{s} ; \mathrm{vf}=40 \mathrm{~mm} / \mathrm{min}$

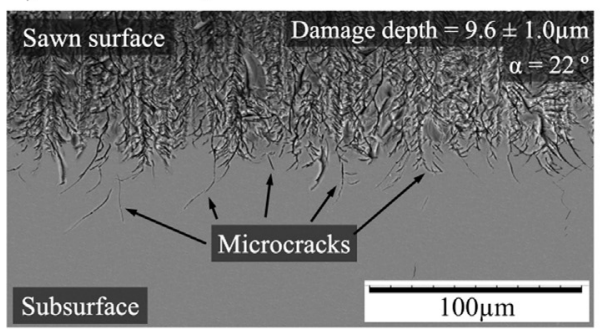

b) $\mathrm{vc}_{\mathrm{c}}=10 \mathrm{~m} / \mathrm{s} ; \mathrm{vf}=40 \mathrm{~mm} / \mathrm{min}$

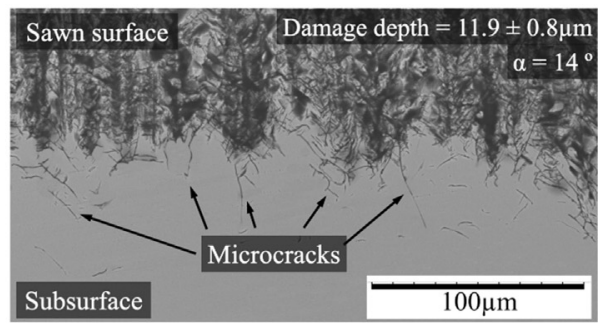

d) $\mathrm{vc}=20 \mathrm{~m} / \mathrm{s} ; \mathrm{vf}=20 \mathrm{~mm} / \mathrm{min}$

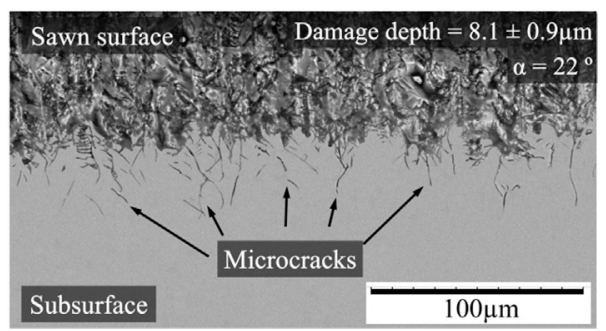

Fig. 10. SEM micrographs of subsurface of the mono-Si specimens sawn with $T_{\text {wire }}=20 \mathrm{~N}$.

mono-Si cutting by diamond wire sawing experiments, it can be stated that $\mathrm{v}_{\mathrm{c}}=10 \mathrm{~m} / \mathrm{s}$ is the threshold for the phase transformation, and an increase in $\mathrm{v}_{\mathrm{c}}$ generates a more intense phase transformation, which leads to the amorphization of the silicon. In this regard, an increase in $\mathrm{v}_{\mathrm{c}}(10,15$ and $20 \mathrm{~m} / \mathrm{s})$ results in a sawn surface with a greater presence of residual phases, which indicates the ductile removal mode for the mono-Si chips. This can be seen in Fig. 9 ( $a, b, c$ and d), where the bandwidth and intensity of the a-Si phase observed on the Raman spectra increase progressively.

\subsection{Subsurface damage}

The SEM micrographs in Fig. 10 show the subsurface damage in the form of microcracks propagated from the surface to the subsurface. These microcracks are formed mainly due to the high brittleness and hardness of the mono-Si, as described by Lawn and Wilshaw (1975). During penetration of the diamond grains, fragile fracture takes place before plastic deformation occurs, leading to the nucleation and propagation of microcracks into the subsurface of the mono-Si specimen.

According to the subsurface damage analysis reported in Fig. 10, the measured average depth of the microcracks was within the expected range (between 2 and $20 \mu \mathrm{m}$ from the surface) (Möller, 2014). It can be observed that microcracks propagated mainly from the bottom of the grooves of the sawn surface. This is consistent with the restricted orientation of the diamond grains on the wire surface that introduces uniformly aligned microcracks along these periodic grooves. Moreover, many of the microcracks were median microcracks and slightly oblique, as also reported by Xiao et al. (2019). This supports the hypothesis that lateral microcracks propagate to the surface and contribute to fragmented chip formation.

With regard to the cutting parameters, an increase in $\mathrm{v}_{\mathrm{f}}$ resulted in deeper subsurface microcracks. As seen in Fig. 10a and 10b, increasing $\mathrm{v}_{\mathrm{f}}$ from 20 to $40 \mathrm{~mm} / \mathrm{min}$ resulted in an increase in the average depth of the microcracks from $9.2( \pm 1.1)$ to $11.9( \pm 0.8) \mu \mathrm{m}$. According to Gao et al. (2016), this increase in the microcrack depth occurs due to the high force per grain, which leads to a greater penetration depth of the kinematic cutting edges and, consequently, higher pressure on the workpiece material. This is in agreement with Klocke (2008), who stated that a higher force per grain results in deeper microcracks.

In contrast, when the increase of $\mathrm{v}_{\mathrm{c}}$ from 10 to $15 \mathrm{~m} / \mathrm{s}$ (see Fig. $10 \mathrm{~b}$ and 10c), the average depth of the microcracks decreased from $11.9( \pm 0.8)$ to $9.6( \pm 1.0) \mu \mathrm{m}$. This reduction may be because an increase in $\mathrm{v}_{\mathrm{c}}$ leads to a lower $\mathrm{h}_{\mathrm{cu}}$ value of the diamond grains and reduces the nucleation and propagation of microcracks.

As seen in the Fig. 10d, increasing $\mathrm{v}_{\mathrm{c}}$ (from 15 to $20 \mathrm{~m} / \mathrm{s}$ ) and decreasing $\mathrm{v}_{\mathrm{f}}$ (from 40 to $20 \mathrm{~mm} / \mathrm{min}$ ) caused a significant decrease in the subsurface damage, which resulted in an average microcrack depth of $8.1( \pm 0.9) \mu \mathrm{m}$. The microcrack depth analysis showed that for the cutting conditions investigated in this study, lower $\mathrm{v}_{\mathrm{f}}$ and higher $\mathrm{v}_{\mathrm{c}}$ results in the lowest microcrack depth. This behavior can be attributed to a smaller undeformed chip thickness $\left(\mathrm{h}_{\mathrm{cu}}\right)$ and lower force per grain of the diamond grains, leading to less damage to the surface integrity, as verified by the reduction in the microcrack depth.

The average values for the microcrack depth measured under different cutting parameters are shown in Fig. 11. It was found that the microcracks became deeper with an increase in $\mathrm{v}_{\mathrm{f}}$, for the same $\mathrm{v}_{\mathrm{c}}$ and for both wire tensions ( $T_{\text {wire }}$ ), because this increase allow the $h_{\text {cu,crit }}$ for ductile-to-brittle mode transition to be exceeded. This generates deeper microcrack at the subsurface of the mono-Si specimen. The microcracks depth is associated with the morphological characteristics and increases when more craters are present on the sawn surface, exhibited by a high value for the surface roughness. This suggests that the surface morphology is close with subsurface damage. According to the ANOVA results, with a variation in $\mathrm{v}_{\mathrm{f}}$ from 20 to $40 \mathrm{~mm} / \mathrm{min}$ the microcrack depth increased by up to $18 \%$ (p-value $=0.000169$ ).

On increasing $\mathrm{v}_{\mathrm{c}}$ and keeping $\mathrm{v}_{\mathrm{f}}$ constant, for both conditions of $\mathrm{T}_{\text {wire, }}$, there was a decrease in the microcrack depth. As previously mentioned, the highest $\mathrm{v}_{\mathrm{c}}$ allows a reduction in the tangential and normal loads of the active diamond grains. Under this condition, there is a lower force per grain, which decreases significantly the initiation and propagation of subsurface microcracks and, consequently, reduces the subsurface damage depth. The ANOVA analysis showed that an increase in $\mathrm{v}_{\mathrm{c}}$ results in a reduction in the microcrack depth of up to $20 \%$ (p-value $=0.000003$ ).

Regarding the cutting parameter $\mathrm{T}_{\text {wire, }}$ this did not significantly affect the average microcrack depth, as seen in Fig. 11. In the ANOVA analysis, the p-value for the results obtained on increasing $\mathrm{T}_{\text {wire }}$ from 20 to $30 \mathrm{~N}$ was 0.416201 , which is higher than $\alpha=0.05$. This behavior demonstrates that there is no difference between the average values obtained with a variation in the wire tension $\left(\mathrm{T}_{\text {wire }}\right)$ under the conditions analyzed in this study. 
a)

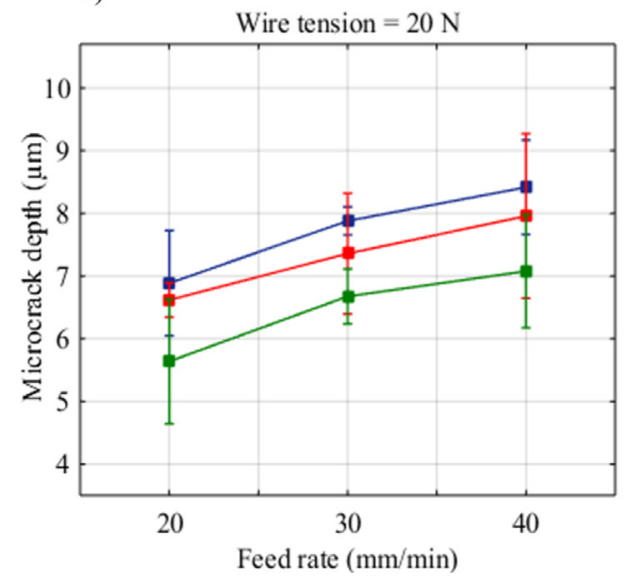

b)

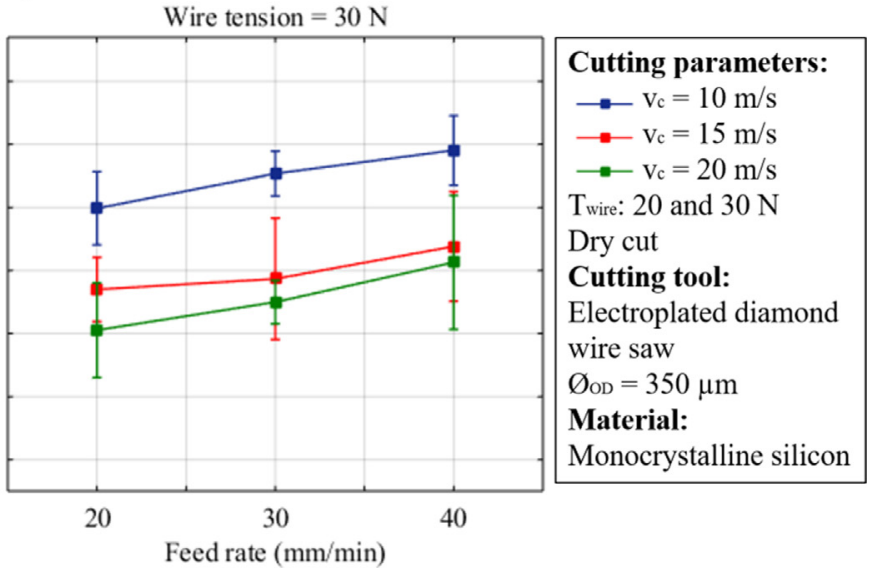

Fig. 11. Influence of the cutting parameters on the subsurface microcrack depth.

\section{Conclusions}

The cutting of mono-Si using the diamond wire sawing process was experimentally investigated. The experiments were performed applying different cutting parameters in order to evaluate their influence on the surface integrity of the cut mono-Si specimen. Aspects of the brittleductile transition phenomenon were discussed and supported by the surface morphology, surface roughness, identification of the material removal mechanism by residual crystalline phase on the sawn surface and depth of subsurface microcrack damage. Based on the experimental results obtained, it can be concluded that:

i. The sawn surface morphology exposed regions which had undergone material removal in the fragile and ductile modes. The predominant mechanism is dependent on the input cutting parameters. An increase in $\mathrm{v}_{\mathrm{f}}$ led to the formation of more fractures associated with the fragile mode on the sawn surface. An increase in $\mathrm{v}_{\mathrm{c}}$ favored material removal in the ductile mode, reducing the surface damage. The sawn surfaces analyzed exhibited similar morphology for the two wire tensions $\left(\mathrm{T}_{\text {wire }}\right)$ tested.

ii. An increase in $\mathrm{v}_{\mathrm{c}}$ resulted in a slight reduction in $\mathrm{S}_{\mathrm{a}}$, and increasing $v_{f}$ promoted the higher $S_{a}$ values. This correlation between the $v_{c}$ and $v_{f}$ parameters and the $S_{a}$ value exhibited a similar behavior for both $\mathrm{T}_{\text {wire }}$ values. For $\mathrm{T}_{\text {wire }}=30 \mathrm{~N}$, the $\mathrm{S}_{\mathrm{a}}$ value increased significantly when compared with the specimens sawn using $\mathrm{T}_{\text {wire }}=20 \mathrm{~N}$. The results for the $\mathrm{S}_{\mathrm{a}}$ parameter also showed a correlation with the surface morphology observed from the SEM analysis.

iii. Raman spectra of the fractured regions exhibited the presence of the Si-I phase, which corresponds to the pure crystal phase of silicon. With a reduction in $\mathrm{v}_{\mathrm{f}}$ and an increase in $\mathrm{v}_{\mathrm{c}}$ the sawn surface presented less fractures and more smooth areas with grooves aligned in the wire cutting direction. The grooves exhibited the metastable phases Si-XII and Si-III, as well as the a-Si phase, which indicates that the surface underwent phase transformation due to the grain/ silicon contact pressure. The cutting parameters $\mathrm{v}_{\mathrm{c}}$ and $\mathrm{v}_{\mathrm{f}}$ both contributed significantly to the surface formation in the ductile regime, which was evidenced by the presence of the a-Si phase. The variation in $\mathrm{T}_{\text {wire }}$ had no significant effect on the phase transformation of the sawn surface.

iv. The microcracks in the subsurface originated mainly from the bottom of the machined grooves during the cut. An increase in $v_{f}$ resulted in deeper microcracks, whereas increasing $v_{c}$ resulted in lower microcrack depths. A decrease in $\mathrm{v}_{\mathrm{f}}$ together with an increase in $\mathrm{v}_{\mathrm{c}}$ led to lower subsurface microcracks damage. These results were observed for both wire tensions $\left(\mathrm{T}_{\text {wire }}\right)$ tested. The $\mathrm{T}_{\text {wire }}$ no present significate effect on the microcrack depth.

The experimental results for the surface integrity of mono-Si cut using the diamond wire sawing process under different cutting conditions showed that the cutting parameters have a significant influence on the sawn surface quality and the brittle-ductile transition of the mono$\mathrm{Si}$ specimen. In future research the sawing forces could be measured to establish a correlation between the cutting parameters and the formation of subsurface microcracks in the mono-Si specimen.

\section{Declaration of Competing Interest}

The authors declare that they have no known competing financial interests or personal relationships that could have appeared to influence the work reported in this paper.

\section{Acknowledgements}

The authors would like to thank the Coordination for the Improvement of Higher Education Personnel (CAPES) for the financial support; Saint-Gobain Abrasives for kindly providing the electroplated diamond wires and the Materials Laboratory (LabMat) at UFSC.

\section{References}

Bidiville, A., Wasmer, K., Kraft, R., Ballif, C., 2009. Diamond wire-sawn silicon wafers from the lab to the cell production. In: 24th Eur. Photovolt. Sol. Energy Conf. Exhib. pp. 1400-1405.

Bifano, T.G., Dow, T.A., Scattergood, R.O., 1991. Ductile-regime grinding: a new technology for machining brittle materials. J. Eng. Ind. 113, 184. https://doi.org/10. 1115/1.2899676.

Chen, K., Liu, Y., Wang, X., Zhang, L., Su, X., 2015. Novel texturing process for diamondwire-sawn single-crystalline silicon solar cell. Sol. Energy Mater. Sol. Cells 133, 148-155. https://doi.org/10.1016/j.solmat.2014.11.016.

Chung, C., Le, V.N., 2015. Depth of cut per abrasive in fixed diamond wire sawing. Int. J. Adv. Manuf. Technol. 80, 1337-1346. https://doi.org/10.1007/s00170-015-7089-z.

Costa, E.C., dos Santos, C.P., Xavier, F.A., Weingaertner, W.L., 2019. Influence of diamond wire sawing parameters on subsurface microcracks formation in monocrystalline silicon wafer. In: ABCM (Ed.), 25th ABCM International Congress of Mechanical Engineering. ABCM, Uberlândia - MG, Brazil, pp. 1-8. https://doi.org/ 10.26678/abcm.cobem2019.cob2019-1574.

Gao, Y., Ge, P., Liu, T., 2016. Experiment study on electroplated diamond wire saw slicing single-crystal silicon. Mater. Sci. Semicond. Process. 56, 106-114. https://doi.org/ 10.1016/j.mssp.2016.08.003.

Gao, Y., Ge, P., Zhang, L., Bi, W., 2019. Material removal and surface generation mechanisms in diamond wire sawing of silicon crystal. 104642. Mater. Sci. Semicond. Process. 103. https://doi.org/10.1016/j.mssp.2019.104642.

Jackson, M.J., Davim, J.P., 2011. Machining with Abrasives, Machining with Abrasives. Springer, US, Boston, MA https://doi.org/10.1007/978-1-4419-7302-3.

Kayabasi, E., Ozturk, S., Celik, E., Kurt, H., 2017. Determination of cutting parameters for silicon wafer with a Diamond Wire Saw using an artificial neural network. Sol. 
Energy 149, 285-293. https://doi.org/10.1016/j.solener.2017.04.022.

Klocke, F., 2008. Manufacturing Process 2: Grinding, Honing, Lapping, RWTH. ed. Springer, Berlim - Germany.

Knoblauch, R., Boing, D., Weingaertner, W.L., Wegener, K., Kuster, F., Xavier, F.A., 2018. Investigation of the progressive wear of individual diamond grains in wire used to cut monocrystalline silicon. Wear 414-415, 50-58. https://doi.org/10.1016/j.wear. 2018.07.025.

Knoblauch, R., Costa, V.M.R.J., Weingaertner, W.L., Xavier, F.A., Wegener, K., Costa, J.V.M.R., Weingaertner, W.L., Xavier, F.A.A.F.A., Wegener, K., Da Silveira, C.A. Weingaertner, W.L., Xavier, F.A.A.F.A., Wegener, K., 2017a. Endless diamond wire saw for monocrystalline silicon cutting. In: 59th Ilmenau Scientific Colloquium. Technische Universität Ilmenau, Ilmenau, Germany, pp. 1-12.

Knoblauch, R., da Silveira, C.A., de Campos, J.E.S., Weingaertner, W.L., Xavier, F.A., Wegener, K., 2017b. Test rig for welding diamond wires into a loop. In: Proc. Fifth Intl. Conf. Adv. Civil Struct. Mech. Eng. - CSM 2017, pp. 37-41. https://doi.org/10. 15224/978-1-63248-132-0-38.

Kumar, A., Kaminski, S., Melkote, S.N., Arcona, C., 2016. Effect of wear of diamond wire on surface morphology, roughness and subsurface damage of silicon wafers. Wear 364-365, 163-168. https://doi.org/10.1016/j.wear.2016.07.009.

Lawn, B., Wilshaw, R., 1975. Indentation fracture: principles and applications. J. Mater. Sci. 10, 1049-1081. https://doi.org/10.1007/BF00823224.

Liu, T., Ge, P., Bi, W., Gao, Y., 2017a. Subsurface crack damage in silicon wafers induced by resin bonded diamond wire sawing. Mater. Sci. Semicond. Process. 57, 147-156. https://doi.org/10.1016/j.mssp.2016.10.021.

Liu, T., Ge, P., Bi, W., Wang, P., 2017b. Fracture strength of silicon wafers sawn by fixed diamond wire saw. Sol. Energy 157, 427-433. https://doi.org/10.1016/j.solener. 2017.08 .063$.

Marinescu, I.D., Hitchiner, M.P., Uhlmann, E., Rowe, W.B., Inasaki, I., 2015. Handbook of Ceramics Grinding and Polishing, 1st ed, Handbook of Ceramics Grinding and Polishing. Elsevier, Waltham, USA. https://doi.org/10.1016/B978-1-4557-7858-4. 00011-X.

Möller, H.J., 2014. Wafer processing. In: Peter RudolphPeter Rudolph (Ed.), Handbook of
Crystal Growth: Bulk Crystal Growth. Elsevier B.V., Schönefeld - Germany, pp. 715-755 https://doi.org/10.1016/B978-0-444-63303-3.00018-3.

Montgomery, D.C., Runger, G.C., 2014. Applied Statistics and Probalisty for Engineers, 6th ed. John Wiley \& Sons Inc, New York, USA.

Ozturk, S., Aydin, L., Kucukdogan, N., Celik, E., 2018a. Optimization of lapping processe of silicon wafer for photovoltaic applications. Sol. Energy 164, 1-11. https://doi.org/ 10.1016/j.solener.2018.02.039.

Ozturk, S., Aydin, L., Celik, E., 2018b. A comprehensive study on slicing processes optimization of silicon ingot for photovoltaic applications. Sol. Energy 161, 109-124. https://doi.org/10.1016/j.solener.2017.12.040.

Pala, U., Kuster, F., Wegener, K., 2020. Characterization of electroplated diamond wires and the resulting workpiece quality in silicon sawing. J. Mater. Process. Technol. 276, 1-9. https://doi.org/10.1016/j.jmatprotec.2019.116390.

Suzuki, T., Nishino, Y., Yan, J., 2017. Mechanisms of material removal and subsurface damage in fixed-abrasive diamond wire slicing of single-crystalline silicon. Precis. Eng. 50, 32-43. https://doi.org/10.1016/j.precisioneng.2017.04.011.

Wang, B., Melkote, S.N., Saraogi, S., Wang, P., 2020. Effect of scratching speed on phase transformations in high-speed scratching of monocrystalline silicon. Mater. Sci. Eng. A 772, 138836. https://doi.org/10.1016/j.msea.2019.138836.

Wu, H., 2016. Wire sawing technology: A state-of-the-art review. Precis. Eng. 43, 1-9. https://doi.org/10.1016/j.precisioneng.2015.08.008.

Wu, H., Melkote, S.N., 2012. Effect of crystallographic orientation on ductile scribing of crystalline silicon: Role of phase transformation and slip. Mater. Sci. Eng. A 549, 200-205. https://doi.org/10.1016/j.msea.2012.04.034.

Xiao, H., Wang, H., Yu, N., Liang, R., Tong, Z., Chen, Z., Wang, J., 2019. Evaluation of fixed abrasive diamond wire sawing induced subsurface damage of solar silicon wafers. J. Mater. Process. Technol. 273. https://doi.org/10.1016/j.jmatprotec.2019. 116267.

Yu, X., Wang, P., Li, X., Yang, D., 2012. Thin Czochralski silicon solar cells based on diamond wire sawing technology. Sol. Energy Mater. Sol. Cells 98, 337-342. https:// doi.org/10.1016/j.solmat.2011.11.028. 